\title{
Chronic lactose intake modifies the gastric emptying of monosaccharides but not of disaccharides in weanling rats
}

\section{E.A.L. da-Costa-Pinto ${ }^{1}$ and E.F. Collares ${ }^{1,2}$}

\author{
'Departamento de Pediatria and ${ }^{2}$ Núcleo de Medicina e Cirurgia Experimental, \\ Faculdade de Ciências Médicas, Universidade Estadual de Campinas, \\ 13081-970 Campinas, SP, Brasil
}

\section{Correspondence}

E.A.L. da-Costa-Pinto

Departamento de Pediatria

Faculdade de Ciências Médicas

Universidade Estadual de Campinas

13081-970 Campinas, SP

Brasil

Fax: 55 (019) 239-8260

Research supported by FAEP

(No. 0773/93). Publication

supported by FAPESP.

Received July 17, 1996

Accepted March 31, 1997

\begin{abstract}
Ninety-six weanling male Wistar rats were fed for four weeks one of two different chows: a normal rat chow containing $55.5 \%(\mathrm{w} / \mathrm{w})$ starch (control group, $\mathrm{N}=48$ ) or a rat chow in which starch was partially replaced by lactose, in such a way that the experimental group $(\mathrm{N}=48)$ received $35.5 \%(\mathrm{w} / \mathrm{w})$ starch and $20 \%(\mathrm{w} / \mathrm{w})$ lactose. The gastric emptying of fluid was then studied by measuring the gastric retention of four test meals containing lactose $(5 \%$ or $10 \%, \mathrm{w} / \mathrm{v})$ or glucose + galactose $(5 \%$ or $10 \%, \mathrm{w} / \mathrm{v})$. Homogenates of the small intestine were assayed for lactase activity. The gastric retention values were obtained $15 \mathrm{~min}$ after orogastric infusion of the liquid meals. The median values for gastric retention of the 5\% lactose solutions were $37.7 \%$ for the control group and $37.0 \%$ for the experimental group $(\mathrm{P}>0.02)$. For the $10 \%$ lactose solution the median values were $51.2 \%$ and $47.9 \%$ $(\mathrm{P}>0.02)$ for the control and experimental groups, respectively. However, for the $2.5 \%$ glucose $+2.5 \%$ galactose meal the median gastric retention was lower $(\mathrm{P}<0.02)$ in the group fed a lactose-enriched chow $(38.5 \%)$ than in the control group $(41.6 \%)$. For the $5 \%$ glucose $+5 \%$ galactose solution the median values were not statistically different between groups, $65.0 \%$ for the control group and $58.8 \%$ for the experimental group. The median values of the specific lactase activity in the small intestine homogenate was $0.74 \mathrm{U} / \mathrm{g}$ in the control group and $0.91 \mathrm{U} / \mathrm{g}$ in the experimental group. These values were not statistically different $(\mathrm{P}>0.05)$. These results suggest that the prolonged ingestion of lactose by young adult rats changes the gastric emptying of a solution containing 5\% monosaccharides. This adaptation may reflect the desensitization of intestinal nutrient receptors, possibly by an osmotic effect of lactose present in the chow.
\end{abstract}

Key words

- Gastric emptying

- Intestinal motility

- Lactase

- Lactose
Gastric emptying is regulated by the activation of receptors situated in the stomach and in the small intestine (1). In the small intestine, equivalent amounts in calories of lipids, proteins and carbohydrates delay gastric emptying to the same extent as a saline solution (2).
To control the gastric emptying of disaccharides and polysaccharides, the above receptors are only activated following the hydrolysis of carbohydrates (3). Individuals with incomplete hydrolysis of lactose have a lower gastric retention of solutions containing this disaccharide, per unit time, than 
those with normal hydrolysis (4). The same phenomenon has been observed in rats with ontogenic lactase deficiency. In these animals, the gastric retention of a lactose solution up to $10 \mathrm{~min}$ after administration was $20 \%$ lower than that of maltose which is completely hydrolyzed (5).

In adult rats, the prolonged intake of lactose induces a significant increase in lactase activity, although the levels reached are not as high as those observed during lactation (6). At the same time, the large intestine is enlarged, with an increase in wet weight (7). From a functional point of view, the mechanisms of adaptation to prolonged lactose intake lead to a recuperation of unabsorbed liquids and caloric substrate in the colon $(8,9)$. Since there is little information on the gastric responses to this condition, the present study was conducted to investigate the effects of a prolonged intake of lactose on the gastric emptying of this disaccharide and its constituent monosaccharides in young adult rats.

Ninety-six 4-week old male Wistar rats were studied. The animals were divided into two groups (control and experimental) and were matched for weight and age.

The control group $(\mathrm{N}=48)$ was fed a standard chow containing 55.5\% starch, $20 \%$ casein and $11 \%$ vegetable oil, as well as a mixture of vitamins, mineral salts and codliver fat, for four weeks (10). The experimental group $(\mathrm{N}=48)$ was fed a chow in which starch was partially replaced by monohydrated lactose, so that this group received a chow containing $35.5 \%(\mathrm{w} / \mathrm{w})$ starch and $20 \%(\mathrm{w} / \mathrm{w})$ lactose. Each group was housed in cages containing a maximum of 12 animals each. Tap water and the respective chows were provided ad libitum throughout the four weeks.

The gastric emptying of fluid was studied on the 28th day following a 20-h fast. The control and experimental groups were divided into four subgroups containing 12 animals each, which were then fed either an aqueous lactose solution or an aqueous solution containing equal amounts of glucose + galactose. Two final concentrations ( 5 and $10 \mathrm{~g} / \mathrm{dl}$ ) were tested for each of the solution. The $5 \%$ glucose + galactose solution consisted of $2.5 \%$ glucose and $2.5 \%$ galactose, and the $10 \%$ solution consisted of $5 \%$ of each monosaccharide. Phenol red $(6 \mathrm{mg} / \mathrm{dl})$ was used as a marker (11).

The meals were infused via an orogastric tube in a volume of $2 \mathrm{ml} / 100 \mathrm{~g}$ body weight. After $15 \mathrm{~min}$, the residue remaining in the stomach was aspirated. The orogastric intubation and the recovery of gastric residue were performed as previously described $(11,12)$. Gastric retention was determined by the method of Gupta and Brans (13) and the marker was detected using a Klett photocolorimeter equipped with a green filter. The gastric retention values were compared by the Kruskal-Wallis test at a significance level of 0.10 (14). When the values were significant, the multiple comparisons test was applied, with a $P$ value $\leq 0.02$ indicating a significant difference (15).

Following the gastric emptying test, the small intestine of all animals was separated and homogenized on ice, using a PotterElvejehem homogenizer. Lactase activity was measured in the homogenates using the assay described by Dahlqvist (16).

The median valve of specific lactase activity (U/g small intestine wet weight) was higher in the group fed a lactose-enriched chow $(0.91 \mathrm{U} / \mathrm{g})$ than in the one fed a normal chow $(0.74 \mathrm{U} / \mathrm{g})$, but the difference was not statistically significant $(\mathrm{P}>0.05$, Student $t$ test) (17).

Figure 1 shows the gastric retention of test meals containing 5\% lactose or $2.5 \%$ glucose $+2.5 \%$ galactose solutions. In the control group, the median retention value for the monosaccharide solution was significantly higher than the median value for the lactose-containing test meal (41.6\% vs 37.7\%). These results are consistent with data in the literature (18) and show that, in young adult 
rats with ontogenic lactase deficiency, the gastric emptying of lactose-containing solutions is faster than that of a mixture of monosaccharides. In the experimental group, the median retention value of $2.5 \%$ glucose $+2.5 \%$ galactose solution was not different from the lactose solution (38.5\% vs 37.0\%). Likewise, there was no difference in the median retention value for the lactose-containing meal between the control and experimental groups (37.7\% vs $37.0 \%)$. However, the median retention value for the glucose + galactose meal was significantly lower in the experimental group $(38.5 \%)$ than in the control group $(41.6 \%)$. These results indicate that the intake of the lactose-enriched chow did not interfere with the emptying of the disaccharide-containing solution but did change the emptying pattern of the monosaccharide meal. This alteration probably reflects a down-regulation of intestinal glucose receptors, and may be mediated by the osmotic effect of the chow, a phenomenon which has been reported in humans following the intake of high quantities of glucose (19).

The retention values for the $10 \%$ lactose and $5 \%$ glucose $+5 \%$ galactose solutions are presented in Figure 1. Emptying was similar to that observed with the 5\% solutions; the lactose retention values were lower than those for the glucose + galactose solution and were comparable between the control and experimental groups. Unlike the results for the 5\% concentrations, the retention values for the $10 \%$ monosaccharide solution did not differ between groups, suggesting that the desensitization effect of a lactose-enriched chow observed with less concentrated meals may have been supplanted by the effect of test meal osmolality.

In conclusion, the present results show that, in adult rats with ontogenic lactase

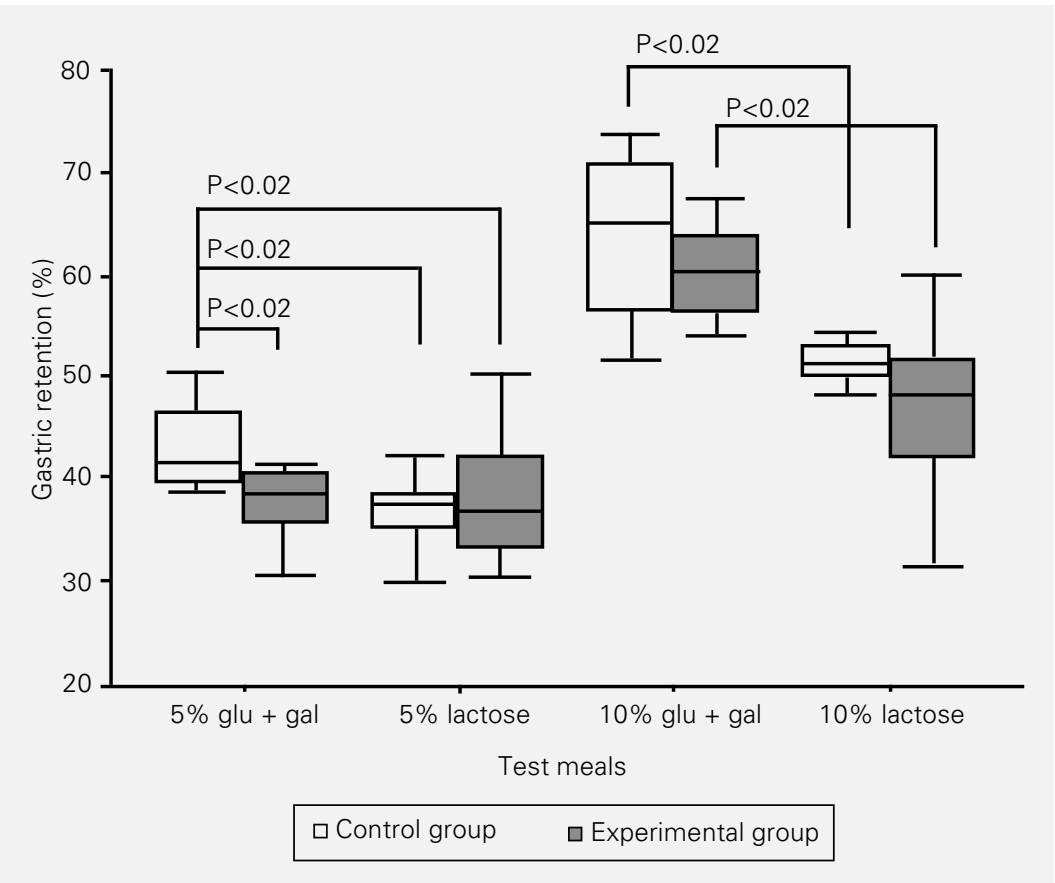

Figure 1 - Gastric retention (\%) 15 min after the infusion of test meals containing $2.5 \%$ glucose $+2.5 \%$ galactose $(5 \%$ glu + gal), $5 \%$ lactose, $5 \%$ glucose $+5 \%$ galactose $(10 \%$ glu + gal) or $10 \%$ lactose. The rats were fed normal chow (control) or chow with $20 \%(\mathrm{w} / \mathrm{w})$ lactose (experimental) for four weeks after which time the gastric retention was measured ( $N=12$ per subgroup). The data are presented as box plots, where the intermediate, lower and upper horizontal lines indicate the median, first and third quartiles of the gastric retention values, respectively, and error bars indicate the maximum and minimum gastric retention values observed. Significant differences between subgroups tested by the KruskalWallis test $(P<0.10)$ followed by the multiple comparisons test $(P<0.02)$ are indicated in the figure.

deficiency, the process of adaptation to chronic lactose intake does not involve an alteration in the gastric emptying of the disaccharide but changes the emptying pattern of the $5 \%$ monosaccharide test meal.

\section{Acknowledgments}

The authors thank Maria Cristina Fernandes Alvin and Marise Mello Carnelossi Brunelli for technical support, and Prof. Stephen Hyslop (Departamento de Farmacologia, FCM, UNICAMP) for reviewing the English text. 


\section{References}

1. Hunt JN \& Knox MT (1968). Regulation of gastric emptying. In: Code CF (Editor), Handbook of Physiology. Vol. IV. American Physiological Society, Washington, 1917-1935.

2. Hunt JN \& Stubbs DF (1975). The volume and energy content of meals as determinants of gastric emptying. Journal of Physiology, 245: 209-225.

3. Elias E, Gibson GJ, Greenwood LF, Hunt JN \& Tripp JH (1968). The slowing of gastric emptying by monosaccharides and disaccharides in test meals. Journal of Physiology, 194: 317-320.

4. Guix-Garcia J, Rodrigo-Gómez JM, Eassel A, Aparisi-Quereda L, Serra-Desfilis MA \& Del Olmo-Pulchat JA (1977). El "test" de tolerancia a la lactosa en relación con el vaciamiento gástrico de soluciones hipertónicas de lactosa. Revista Española de las Enfermedades del Aparato Digestivo, 49: 363-372.

5. Collares EF, Belangero VMS \& Silva PEMR (1991). Gastric emptying of maltose, sucrose, lactose and lactulose in rats with ontogenic lactase deficiency. Brazilian Journal of Medical and Biological Research, 24: 539-542.

6. Leichter J, Goda T, Bhandari SD, Bustamante S \& Koldovsky O (1984). Relation between dietary-induced increase of intestinal lactase activity and lactose digestion and absorption in adult rats. American Journal of Physiology, 247: G729-G735.
7. Collares EF, Rossi A \& Macedo A (1985). Dilatação experimental de ceco e cólon em ratos. I. Indução pela administração continuada de lactose após o desmame. Archives of Gastroenterology of São Paulo, 22: 136-140.

8. Cummings JH \& Englyst HN (1987). Fermentation in the human large intestine and the available substrates. American Journal of Nutrition, 45: 1243-1255.

9. Kim Kyu-Il, Benevenga NJ \& Grummer $\mathrm{RH}$ (1978). Estimation of the fraction of the lactose diet available for fermentation in the cecum and colon of the rat. Journal of Nutrition, 108: 79-89.

10. AOAC-Association of Official Agricultural Chemists (1965). Official Methods of Analysis of the Association of Official Agricultural Chemists. Washington, 779.

11. Belangero VMS \& Collares EF (1991). Esvaziamento gástrico e acidose metabólica. I. Estudo de um modelo experimental em ratos, empregando uma solução de cloreto de amônio por via orogástrica. Archives of Gastroenterology of São Paulo, 28: 145-190.

12. Bucaretchi F \& Collares EF (1995). Effect of Phoneutria nigriventer spider venom on gastric emptying in rats. Brazilian Journal of Medical and Biological Research, 29: 205-211.
13. Gupta M \& Brans YW (1978). Gastric retention in neonates. Pediatrics, 62: 26-29.

14. Siegel S (1975). A prova de Kruskal-Wallis. In: Siegel S (Editor), Estatística não Paramétrica. McGraw-Hill do Brasil, São Paulo, 209-219.

15. Leach C (1979). Tests for several independent samples - categorical explanatory variable. In: Leach C (Editor), Introduction to Statistics. A Nonparametric Approach for the Social Sciences. John Wiley \& Sons, New York, 148-166.

16. Dahlqvist A (1964). Method for assay of intestinal disaccharidases. Analytical Biochemistry, 7: 18-25.

17. Daniel WW (1978). Estimation. In: Daniel WW (Editor), Biostatistics: A Foundation for Analysis in the Health Sciences. 2nd edn. John Wiley \& Sons, New York, 121 157.

18. Collares EF (1992). Gastric emptying of disaccharides and their monosaccharides in rats with lactase deficiency. Archives of Gastroenterology of São Paulo, 29: 142146.

19. Cunningham KM, Horowitz $M$ \& Read NW (1991). The effect of short-term dietary supplementation with glucose on gastric emptying in humans. British Journal of Nutrition, 65: 15-19. 